\title{
GOVERNMENT SUPPORT FOR SMALL AND MEDIUM-SIZED BUSINESS AND INNOVATIVE ACTIVITIES
}

\author{
Polina KOLISNICHENKO' \\ Uman State Pedagogical University, Ukraine
}

\begin{abstract}
The purpose of the paper is to reveal the conditions of the innovative development of the small and mediumsized entrepreneurship in Ukraine; the problems that suppress the innovative activity and small and medium-sized enterprises development; peculiarities of the tax incentives for the development of the entrepreneurship in the advanced countries and in Ukraine; the main kinds and characteristics of the small and medium-sized enterprises public support. Methodology. The methods of scientific research include: analysis and generalization for studying the main kinds and characteristics of the government support of the small and medium-sized enterprises; dynamic and comparative analysis for studying the problems and factors influencing the development of small and medium enterprises and innovative activity, peculiarities of tax incentives for business development; systemanalytical method for studying the conditions of the innovative development of the small and medium-sized entrepreneurship. Results. The government's financial support priorities should be: optimal application of the fiscal regulation instruments (reduction of the amount of taxes, determination of the criteria for the maximum taxation amount, tax incentives etc.), maintenance of the self-investment of small and medium-sized enterprises as well as investment, financial means of the public influence over the development of the enterprises, effective combination of both direct and indirect forms of the innovative development support. Practical implications. The obtained results can be used in the process of formation and implementation of the small and medium enterprise sector development strategy and innovative activity in the long-term perspective. Value/originality. The obtained data can provide a better understanding of the direction of innovative business development in Ukraine.
\end{abstract}

Key words: small and medium-sized enterprises, conditions, innovative development, government support, tax incentives, direct and indirect forms of support.

JEL Classification: G18, 038

\section{Introduction}

The current state of the economic performance of Ukraine has been stipulated by many peculiar concessions of the innovative activity in the state, uncertainty of the small and medium-sized enterprises development environment, slowdown of investment and financial incentives rate of economic, researchengineering and innovative activity.

The selection of the innovative direction is among those especially popular and pressing present-time issues within the conditions of the effective economic reforming in our country. Nevertheless, the innovative and investment activity of the small and mediumsized enterprises is constantly subject to retardation (Jurinetz, 2014). There are more than enough reasons, in particular, a low financing level of the innovative and scientific-research activity, weak motivation, and inefficiency of incentives to such kind of works, disconnection of science from practice and production processes (Semynozhenko, 2014).
A substantial progress towards the formation of a theory, concepts, methodology of the scientific research of the small and medium-sized enterprises development, peculiarities of the government regulation was made by the following Ukrainian and foreign economists: and others. The theoretical and empirical basis for the development of the small and medium-sized enterprises, government regulation of the innovative activity on different levels of the national economy have become the background for the studies carried out by the following scientists, such as Yu. Bazhal, T. Bova, V. Bondarchuk, T. Vasyltsiv, Z. Varnalii, M. Veber, V. Haets, A. Diehtiar, P. Drucker, E. Dolan, L. Erhardt, Ya. Zhalilo, D. Lindsey, I. Lutsykiv, A. Marshall, I. Mantsurov, Yu. Nikolenko, Yu. Pakhomov, Ye. Panchenko, G. Simon, M. Skyba, O. Ustenko, A. Chukhno, F. Hayek, I. Yukhnovskyi etc. However, the trends for the small and mediumsized entrepreneurship operation in Ukraine within the framework of the government regulation of the innovative activity require further theoretical and applied research.

Corresponding author:

${ }^{1}$ Department of Technology and Tourism Organization, Uman State Pedagogical University.

E-mail: zoryna_yur@ukr.net 
The purpose of the article is to reveal the conditions of the innovative development of the small and mediumsized entrepreneurship in Ukraine; the problems that suppress the innovative activity and small and mediumsized enterprises development; peculiarities of the tax incentives for the development of the entrepreneurship in the advanced countries and in Ukraine; the main kinds and characteristics of the small and medium-sized enterprises public support.

\section{Trends in the small and medium-sized enterprises' innovative activity incentives}

Since 2016 Ukraine has concluded the agreement with EU for the participation of our country in the EU program on $\ll$ COSME, Competitiveness of Small and Medium Enterprises (2014-2020)» aiming at the development and support of the small and mediumsized enterprises. This is the program financed by EU in the amount of $2,3 \mathrm{bln}$. euro and is directed to the creation of the favorable conditions for the development of the small and medium-sized enterprises, realized within the framework of the strategy «Europe 2020» (Moldovan \& Medvedkova, 2015).

Such cooperation within the framework of COSME program will enable:

- the development of the national business environment;

- performance of the internationalization (search of partners in almost 65 countries of the world), will give the opportunity to increase the circle of business and economic relations;

receive high-quality analytical and consulting services, related to export and import activity of the small and medium-sized enterprises;

- lay the groundwork and environment for the enhancement of the role of the small and medium-sized enterprises, culture of the business activity operation (educational programs, seminars, trainings, probation etc.);

- improve the regulatory conditions for the medium-sized enterprises development due to their implementation in the third countries «Small Business Act for Europe» in particular, promote the operation of SME Envoys network;

- bring the domestic legislative environment into accordance with the European standards etc.

It is the innovations commercialization, in other words, the transfer of innovative technologies, search for a foreign partner or an investor aiming to come into the market with the new technological products (service), an effective protection of copyrights and intellectual property rights that is a foreground job of the biggest COSME subprogram - European Enterprisenet work (EEN).

The measures of financial assistance have become among one of the main components of the incentive system and should provide optimal application of the fiscal regulation instruments (reduction of the amount of taxes, determination of the criteria for the maximum taxation amount, tax incentives etc.), maintenance of the self-investment of small and medium-sized enterprises as well as investment, financial means of the public influence over the development of the enterprises.

In many advanced countries there are applied different tax incentives for the development of the innovative activity of the entrepreneurial system, in particular, for the small and medium-sized enterprises, which, first of all is notable for the correlation between the tax liabilities to the research and development expenditures and maximum amount of tax liabilities (Table 1).

Table 1

Tax allowances for entrepreneurship development in advanced countries

\begin{tabular}{|c|c|l|l|}
\hline \multicolumn{2}{|c|}{ Countries } & $\begin{array}{c}|c| \\
\text { Ratio of tax } \\
\text { deductions to R\&D } \\
\text { expenses }\end{array}$ & \multicolumn{1}{|c|}{$\begin{array}{c}\text { Maximum tax } \\
\text { deductions }\end{array}$} \\
\hline \multirow{2}{*}{ USA } & $\begin{array}{l}3-5 \% \text { of the total, } \\
20 \% \text { for costs } \\
\text { exceeding the norm }\end{array}$ & 25\% of tax \\
\hline Japan & By 2008 & $\begin{array}{l}\text { Large companies } \\
8-10 \%,\end{array}$ & 20\% of tax \\
\cline { 2 - 4 } Since 2008 & $\begin{array}{l}\text { Small and medium } \\
\text { enterprises } 12 \%\end{array}$ & $\begin{array}{l}\text { Large enterprises }- \\
30 \% \text { of tax. Small } \\
\text { and medium } \\
\text { enterprises - up to } \\
100 \% \text { of tax }\end{array}$ \\
\hline China & $15 \%$ of the total, & Missing \\
\hline Canada & $20 \%$ of the total & Missing \\
\hline France & $10 \%$ of the total & 16 million euros \\
\hline
\end{tabular}

Source: developed by the author, taking into account (Egorov, 2011)

The gross domestic expenditure stake for research and development is important for the progress of innovative activity of small and medium-sized enterprises in the economically developed countries (Table 2). The leading countries certify the extremely high indicators of the innovative activity development, as long as the governments of these countries allocate a lot of budget money to support the research and development.

In Ukraine, there were also made the attempts to apply the contemporary models of public regulation and tax influence, in particular, an investment tax credit. It provided the change of the income tax payment due date, namely «deferment of income tax payment, granted to the business entity for the specified period with the purpose to increase its financial resources for the implementation of the innovative programs, with subsequent compensation of the deferred amounts in the form of additional tax receipts through the general increase in profits, which will be received as a result of innovative programs implementation» (Yurinets \& Zadorozhny \& Zvir, 2013). Unfortunately, the process 
Table 2

List of countries by research and development spending (\% of GDP)

\begin{tabular}{|l|c|c|c|c|c|}
\hline \multicolumn{1}{|c|}{ Country } & 2000 & 2003 & 2012 & 2013 & 2015 \\
\hline Brazil & 1,05 & 1,1 & 1,3 & 1,3 & 1,2 \\
\hline United Kingdom & 1,81 & 1,81 & 1,82 & 1,82 & 1,83 \\
\hline India & 0,86 & 0,87 & 0,9 & 0,85 & 0,86 \\
\hline Italy & 1,04 & 1,09 & 1,3 & 1,2 & 1,2 \\
\hline China & 1,00 & 1,23 & 1,8 & 1,9 & 2,0 \\
\hline Germany & 2,47 & 2,50 & 2,8 & 2,8 & 2,85 \\
\hline South Korea & 2,65 & 2,96 & 3,6 & 3,7 & 3,8 \\
\hline US & 2,71 & 2,62 & 2,8 & 2,9 & 2,9 \\
\hline Taiwan & 2,05 & 2,16 & 2,3 & 2,35 & 2,4 \\
\hline Ukraine & 1,2 & 1,3 & 0,4 & 0,4 & 0,3 \\
\hline Finland & 3,35 & 3,45 & 3,9 & 3,95 & 3,95 \\
\hline France & 2,15 & 2,20 & 2,3 & 2,3 & 2,35 \\
\hline Sweden & 2,47 & 2,56 & 3,41 & 3,45 & 3,5 \\
\hline Japan & 2,99 & 3,12 & 3,4 & 3,43 & 3,48 \\
\hline
\end{tabular}

Source: developed by the author, taking into account (European statistics)

of implementation and the investment tax credit activity in Ukraine has not been well-proven. In such a way, this fiscal instrument has not found practical use within the national conditions.

The state financial incentives system of the small and medium-sized enterprises' innovative activity provides an effective combination of both direct and indirect forms of the innovative development support. The most popular forms and methods of the small and mediumsized innovative activity promotion are shown in Table 3.

Table 3

Forms and methods of supporting SMEs innovative activity

\begin{tabular}{|c|c|}
\hline $\begin{array}{c}\text { Direct support for innovation } \\
\text { activities of SMEs }\end{array}$ & $\begin{array}{c}\text { Indirect support for innovation } \\
\text { activities of SMEs }\end{array}$ \\
\hline $\begin{array}{l}\text { - implementation of public } \\
\text { innovation programs for SMEs; } \\
\text { - grant for Research and } \\
\text { Development; } \\
\text { - direct financing to firms (up to } \\
\text { 50\% on the cost of developing } \\
\text { new technology); } \\
\text { - interest-free loans; } \\
\text { - creation of a technology } \\
\text { innovation fund; } \\
\text { - free package provision of } \\
\text { services; } \\
\text { - exemption benefits from } \\
\text { payment of customs duties, etc. }\end{array}$ & $\begin{array}{l}\text { - preferential taxation of } \\
\text { innovative enterprises; } \\
\text { - preferential lending; } \\
\text { - state guarantees for business } \\
\text { loans, } \\
\text { - tax depreciation allowances; } \\
\text { - stimulating the development } \\
\text { of securities markets; } \\
\text { - reduction of tax rate on } \\
\text { dividends and other income; } \\
\text { - stimulating the development } \\
\text { of business angels network; } \\
\text { - creation and development of } \\
\text { venture business, etc. }\end{array}$ \\
\hline
\end{tabular}

Source: developed by the author, taking into account (Marchuk, 2006)

Instability of the applicable legislation (annulment of the tax relief for the people drafting the projects, indirect maintenance of the technological parks); withdrawal from the duty on imports while importing the new technologies to Ukraine, as well as components and materials that are not produced in the country with the purpose to implement the innovative projects by the technological parks; some renewal of the customs privileges and tax incentives for those, implementing the innovative projects has a negative effect on the development of the innovative activity and the small and medium-sized enterprises.

\section{Kinds and characteristics of the government support of small and medium-sized enterprises}

The development of small and medium-sized business requires the maintenance of the state infrastructure facilities, conducting support and promotion of the small and medium-sized enterprises to the development, in particular, the innovative one, and within the state limits, the local and regional small and medium-sized enterprises development programs.

Particularlyimportantforthe system of the publicsupport of small and medium-sized enterprises and infrastructure facilities of small and medium-sized enterprises is the financial, consulting and information support, promotion of export performance, training, education of managers, entrepreneurs, support in the scientific and technological sphere, the innovative domain and sphere of the industrial goods production (Table 4).

The systemic issues hamper the effective development of small and medium-sized enterprises in Ukraine. The essential barrier features for the small and mediumsized enterprises operation primarily depend on the relationships between the business entities and regulatory authorities, which at this stage are complicated and not transparent, regulatory policy of the state, which is imperfect, besides, the national investment and innovative climate of which is far removed from the favourable one.

A great deal of problems has been stipulated by the following factors: absence of conditions for the successful development of the small and mediumsized enterprises; the small and medium sized enterprises operation maintenance policy is ineffective, unproductive and inconsecutive; one may feel an excessive interference of the public authorities into the financial and economic activity of the small and medium-sized enterprises, low level of the legal culture of the entrepreneurs and regulatory authorities; low level of the innovative culture.

In the course of the small and medium-sized enterprises and innovative activity development it is necessary to distinguish the following critical problems: - complexity, inconsistency of the customs and fiscal fields which is characterized by the retardation of the entrepreneurship development process;

- weak development of different forms of cooperation in the innovative, scientific and technological sector;

- absence of results of the implemented entrepreneurship innovative development maintenance instruments; 
Table 4

Kinds and characteristics of the government support of SMEs

\begin{tabular}{|c|c|}
\hline Kinds of support & Characteristics \\
\hline $\begin{array}{l}\text { Support in the scientific, technical } \\
\text { and manufacturing industries }\end{array}$ & $\begin{array}{l}\text { 1) financial support for infrastructure supporting SMEs in innovation, science, technical and } \\
\text { manufacturing industries and manufacturing; } \\
\text { 2) promotion of venture funds and enterprises; } \\
\text { 3) improvement of the system of an economic development incentive; } \\
\text { 4) preparation and implementation technology transfer actions and plans; } \\
\text { 5) creating a favorable environment for innovative SMEs and start-ups and the signing of subcontract } \\
\text { agreements; } \\
\text { 6) creation of conditions for the cooperation between SMEs and large enterprises; } \\
\text { 7) promotion of foreign investment and the development of mutually beneficial international } \\
\text { innovation cooperation. }\end{array}$ \\
\hline Consultation support & $\begin{array}{l}\text { 1) support for innovative infrastructure supporting SMEs (business consulting services firms); } \\
\text { 2) business consulting and access to information online; } \\
\text { 3) creation networks and technology platforms that can help interested entities to find relevant } \\
\text { information. }\end{array}$ \\
\hline Financial support & $\begin{array}{l}\text { 1) credit and loan guarantees for SMEs; } \\
\text { 2) partial compensation of lease and guarantees payments; } \\
\text { 3) partial compensation of interest rates on loans (for the implementation of innovative projects); } \\
\text { 4) loans for the implementation of advanced technologies; } \\
\text { 5) start-up financing and start-up loans; } \\
\text { 6) financing to increase the use of renewable energy and energy efficiency technologies; } \\
\text { 7) compensation of expenditures aimed at supporting cooperation between SMEs and large } \\
\text { businesses, etc; } \\
\text { 8) compensation expenditures on the creation of cooperation between SMEs and large business, ets. }\end{array}$ \\
\hline Information support & $\begin{array}{l}\text { 1) creation and provision of information systems development, information and telecommunication } \\
\text { networks; } \\
\text { 2) promotion of entrepreneurship and innovative SMEs through Internet and mobile technology; } \\
\text { 3) provide information regarding the implementation of state, regional and local programs for SMEs } \\
\text { development } \\
\text { 4) provide information regarding the current efficiency and effectiveness of the use of public } \\
\text { stimulation of SMEs; } \\
\text { 5) provide information regarding the development of SMEs and infrastructure, etc. }\end{array}$ \\
\hline $\begin{array}{l}\text { Support the ongoing learning and } \\
\text { development of managers and } \\
\text { professional staff }\end{array}$ & $\begin{array}{l}\text { 1) creation and development of innovative firms' networks, in particular business incubators; } \\
\text { 2) development and implementation of educational and scientific programs; } \\
\text { 3) formation of conditions for increasing the level of competence, professional knowledge and } \\
\text { business qualities of specialists; } \\
\text { 4) scientific, educational and methodological support of SMEs; } \\
\text { 5) participation in international programs of experience exchange (qualification raising and staff } \\
\text { retraining, transfer of technologies). }\end{array}$ \\
\hline Export support & $\begin{array}{l}\text { 1) cooperation with foreign organizations; } \\
\text { 2) promotion products and services to international markets; } \\
\text { 3) formation of conditions for developing an export business plan; } \\
\text { 4) access to foreign information and communication networks for the search of business partners. }\end{array}$ \\
\hline
\end{tabular}

Source: developed by the author

- low level of the managers, entrepreneurs and personnel's competence; low level of people's erudition on the development prospects based on innovative activity;

- bureaucracy, insufficient investment and financial support of the innovative activity, scientific and research works on all levels of the economic activity.

The settlement of the above-mentioned problem tasks requires the support strategy formation and implementation for the operation and development of the small and medium-sized enterprises for the longterm perspective. Such strategy should be focused on creation of the favourable external environment for the development of small and medium-sized enterprises, formation of the complex mechanism to guarantee the rights, interests of the small and medium-sized enterprises, construction of relationships between the authorities and small and medium-sized entrepreneurs, on the basis of the constructive and trust-based principles.

\section{Conclusion}

The carried out analysis of the state of the innovative activity and small and medium-sized business development in Ukraine within the context of the public support is indicative of substantial negative trends of 
the innovative process in the country, cutting of the enterprises innovative development rate, complexity of the small and medium-sized entrepreneurship operating procedures, reduction of the financial maintenance in the innovative sphere in comparison with separate countries of the world.

Because of the mobility, adaptedness, the flexibility of the activity, receptivity to the innovations, the small and medium-sized enterprises should become the key ones for the promotion of the innovations' development and implementation.
That is why the public support should primarily be concentrated on the small and medium-sized enterprises development, their innovative activity. A special consideration, within the context of the small and medium-sized enterprises public support should be given to financial, consulting, information support, promotion of export performance, training and managers (entrepreneurs') education, support in the research and technical, innovative domain and a sphere of the industrial products manufacture.

\section{References:}

Egorov, I. (2011). Innovation Policy: European Experience and Recommendations for Ukraine, Kyiv, Phenix, Tom $1,214 \mathrm{p}$.

Marchuk, L. P. (2006). Stimulation of innovative activity of small and medium enterprises: world experience, Agricultural science of the Black Sea region, 4: 92-97.

Semynozhenko, V. (2014). In 2014 the Government will continue the policy of forming an innovation infrastructure. Government portal. Retrieved September 13, 2017 from http://www.nas.gov.ua/siaz/Ways_of development of_Ukrainian_science/article/13116.2.065.pdf

Moldovan, O.O. ., Medvedkova, N.S. (2015). Concerning the expediency of introducing tax incentives for innovation and investment development in Ukraine. Analytical note. Retrieved June 15, 2017 from http://www.niss.gov.ua/ articles/1315/

Yurinets, Z. V., Zadorozhny, D. B., \& Zvir, V. V. (2013). Development of innovation activity in Ukraine and in the world. Scientific herald of the National Forestry University of Ukraine: a collection of scientific and technical works, 23.10: 282-291.

European statistics. Retrieved August 15, 2017 from http://epp.eurostat.ec.europa.eu/portal/page/portal/ eurostat/home/.

Jurinetz, S. (2014). Analyse der innovativen Tatigkeit von Unternehmen in der Ukraine im Kontext ihrer globalen Wettbewerbsfahigkeit. The world economy. Global and country-specific aspects, 35: 291-298.

\section{ПОЛИНа КОЛИСНИЧЕНКО}

\section{ГОСУДАРСТВЕННАЯ ПОДДЕРЖКА СУБЪЕКТОВ МАЛОГО И СРЕДНЕГО БИЗНЕСА} И ИННОВАЦИОННОЙ ДЕЯТЕЛЬНОСТИ

Аннотация. Целью работы является выявление условий инновационного развития малого и среднего предпринимательства в Украине; проблем и факторы, влияющие на развитие малого и среднего предпринимательства и инновационной деятельности; особенностей налоговых стимулов для развития предпринимательства в разных странах; основных видов и характеристик государственной поддержки субъектов малого и среднего предпринимательства. Методика. В работе использовались методы научного исследования: анализ и обобщение - для изучения основных видов и характеристик государственной поддержки субъектов малого и среднего предпринимательства; динамического и сравнительного анализа для изучения проблем и факторов, влияющих на развитие малого и среднего предпринимательства и инновационной деятельности, особенностей налоговых стимулов для развития предпринимательства; системно-аналитический метод - для изучения условий инновационного развития малого и среднего предпринимательства. Результаты. Приоритетной задачей государственной финансовой поддержки должно стать: оптимальное применение инструментов налогового регулирования (уменьшение количества налогов, определение критериев для предельной границы налогообложения, налоговых льгот и т.п.), поддержка самоинвестирования субъектов МСП, эффективное сочетание прямых и косвенных форм поддержки инновационного развития, инвестиционные и финансовые средства воздействия государства на развитие предприятий. Также необходимо совершенствование финансовой, консультационной и информационной поддержки, стимулирования экспортной деятельности, обучения и развития менеджеров, предпринимателей, поддержка в научно-технической, инновационной сфере и сфере производства. Практическое значение. Полученные результаты могут найти отражение в процессе формирования и реализации стратегии поддержки функционирования и развития малых и средних предприятий на долгосрочную перспективу. Значение/оригинальность. Полученные данные способны обеспечить лучшее понимание направления развития инновационной деятельности предпринимательства в Украине. 